\title{
The Enforcement and Effectiveness of the Regional Regulation on Family Resilience in Indonesia in Reducing the Rate of Early Marriage
}

\author{
Zainal Arifin ${ }^{1}$, Heru Susetyo ${ }^{2}$, Djarot Dimas Achmad Andaru ${ }^{3}$, Andini Naulina Rahajeng $^{4}$, \\ Maudyna $^{5}$, Velladia Zahra Taqiya ${ }^{6}$ \\ \{vtaqiya@gmail.com $\left.{ }^{6}\right\}$
}

Faculty of Law, Universitas Indonesia, 16424, Indonesia ${ }^{1,2,3,4,5,6}$

\begin{abstract}
The rise of early marriages in Indonesia causes the role of the family to be less than ideal. The role of the Regional Government in implementing policies in building family resilience requires legal instruments, in the form of regional regulations and the Family Resilience Development Policy implemented in line with national policies. Local governments have the authority to make Regional Regulations on family resilience. This research aims to study the effectiveness of the Regional Regulation on Family Resilience in reducing the early marriage rate in Indonesia, strengthening family resilience, and overcoming family problems. This research employs an empirical and comparative approach - the data obtained from the literature study and by interviewing sources and experts. We will analyze each regulation's effectiveness in regulating early marriages and family resilience from the data collected. We would also compare the regulations, finding each strength, weakness, problems, and challenges using Friedman's theory on legal substance, legal structure, and legal culture. Regional regulation on Family Resilience is a great breakthrough for overcoming family problems and strengthening family resilience. Yet, it needs to compromise with legal cultures and legal structures surrounding it. Furthermore, regional regulation needs to be more comprehensive and cover local people's needs and wants. Finally, more studies and research on this issue need to be conducted soon.
\end{abstract}

Keywords: family resilience, early marriages, regional regulation

\section{Introduction}

Early marriages have been proven to impact the family quality. Suffice to say, early marriages rise in Indonesia proven to has a negative impact to the role of family. Based on 2018 data, early marriage is found in all parts of Indonesia. A total of 1,184,100 women aged 20-24 years have married by the age of 18 . During the Covid-19 pandemic, the number of early marriages is increasing. In January-June 2020, 34,000 applications for early marriage dispensation (under 19 years) were submitted, $97 \%$ of which were granted. Even though throughout 2019 , there were only 23,700 requests. The role of the Regional Government in implementing policies in building family resilience requires legal instruments, in the form of regional regulations and the Family Resilience Development Policy implemented in line with national policies. Local governments have the authority to make Regional Regulations on family resilience. 
Hence, this research will discuss family resilience regulations in Banjarmasin, Banten, and Depok and its effects on reducing Indonesia's early marriage rate. This research also compares Banjarmasin, Banten, and Depok's regulations by using Lawrence Friedman's theory. This research aims to study the effectiveness of the Regional Regulation on Family Resilience in reducing the early marriage rate in Indonesia, strengthening family resilience, and overcoming family problems.

\section{Method}

This research employs an empirical and comparative approach - the data obtained from the literature study and by interviewing sources and experts. We will analyze each regulation's effectiveness in regulating early marriages and family resilience from the data collected. We also compare the regulations, finding each strength, weakness, problems, and challenges using Friedman's theory on legal substance, legal structure, and legal culture.

\section{Results and Discussion}

Family resilience is defined as the family's ability to ward off or protect themselves from various life problems or threats from within the family and outside the family, such as the environment, community, community, and country [1]. Based on the Act 52/ 2009 defining the family's resilience and well-being as the family's condition that has tenacity and toughness and contains the physical-material ability to live independently and develop themselves and their families to live harmoniously in improving the welfare of birth and mental happiness [2]. Thus, family resilience concerns an individual or family's ability to harness its potential to face life's challenges. The concept of family resilience and well-being includes the foundations of family legality and integrity, physical resilience, economic resilience, social resilience psychology, and socio-cultural resilience [3]. Based on this paper, we review the regulation about family resilience in three cities in Indonesia: Depok City, Banjarmasin City, and Banten Province.

\subsection{Banjarmasin, South Kalimantan}

The Banjarmasin City Government, along with the Banjarmasin DPRD, ratified the Draft Regional Regulation (Raperda) into a Regional Regulation (PERDA) on Family Resilience Development through Banjarmasin PERDA number 2 of 2018. The Mayor of Banjarmasin, $\mathrm{H}$ Ibnu Sina, stated that this regulation was made to prevent domestic violence, both against women and children. This regulation is also made to give responsibility to the local government and the community, and parents to foster welfare and protect the family. According to religion and the state's guidance, this regulation serves as a motivation to build good family resilience. Therefore, this PERDA does not contain sanctions for the violators. This PERDA is also intended to reduce the number of marriages in Banjarmasin.

Based on BPS data (2008), the number of first marriages performed under 16 is $11.23 \%$ [4]. Early marriage in South Kalimantan as a whole reached 48.4 percent or far above the national average, which was only $4.8 \%$ of the total 60 million marriages in 2010 . South Kalimantan Province was ranked first, with the criteria for the age of $10-14$ years. $5.7 \%$ and 
around $46 \%$ aged $15-19$ years in 2018. Banjarmasin ranks second highest in early marriages in 2017, with 38 cases filing marriage dispensation.

In 2017, based on data prepared by the Pengadilan Agama Kelas 1A Banjarmasin 2017, 2361 cases went to court, with 1731 lawsuits and 630 petition cases. Of these cases, 39 cases were requests for dispensation of marriage. The number of petition cases decided in 2017 was 630 cases, which brought the percentage of dispensation to marriage is $6.19 \%$ [5]. Meanwhile, in 2019, the number of cases decided by the Pengadilan Agama Kelas 1A Banjarmasin 2019 was 2207, covering 1607 lawsuits and 600 petition cases. Of these cases, 85 cases were applications for dispensation of marriage. There were 600 petition cases decided in 2019, which brings the percentage of dispensation to marriage to $0.005 \%$ [6].

Using Lawrence Friedman's theory, the legal structure in Banjarmasin is not well enforced, where the local government has no institution to support the regulations. The local governments do not have any program to implement the Regional Regulation further, too. PKK mothers do the socialization process more than local governments. The women's agency also wants more in-depth socialization about early marriage but is limited by inadequate budgetary funds and human resources [6]. But based on the data shown above, the existence of the PERDA on family resilience in 2018 has a reduced impact on marriage dispensation. As in the legal culture, there's quite a clash between the social norm and the regulation. Society believes that it's better to be a widow multiple times rather than being an old virgin lady. Early marriage is considered as a solution to juvenile delinquency. Hence the rate is high in Banjarmasin.

\subsection{Banten}

The Family Resilience Regulation in Banten was promulgated in October 2018. Chairman of Commission V Banten DPRD, Fitron Nur Ikhsan in his report said, the objectives of the formation of the Regional Regulation on Family Resilience include realizing the quality of families that have balanced mental, physical and material strength, synchronizing family development from various sectors, increasing religious values, structuring families, restrain divorce, improve the economic quality and social resilience of families, improve the quality of children and adolescents through access to information and increase the role and function of families and family protection. This regional regulation also contains the Banten Provincial Government's efforts to provide assistance and facilitation for underprivileged families and reduce poverty.

Related to family resilience, it is known that Banten is one of the provinces with the highest child marriage rate. Child marriage is prone to household problems. Therefore, these child marriage practices could lead to many problems. Based on data, in Banten, around 3 million people living in Banten in 2018 are aged 10 to 24 years or are in the youth group. However, with that number, the age of early marriage is still high. Even Banten occupies the fourth rank out of 34 provinces in Indonesia for early marriage. DPR RI Commission IX member Yayat R Biaro spoke up. Yayat said the high practice of early marriage in Banten is triggered by many factors, one of which is cultural issues. It is a common thing to get married early in Banten. There is a local saying that "Perempuan Jangan sampai jadi perawan tua".

In correlation to the regulation, it accommodates the advocacy of the importance of family resilience. The regulation accommodates cooperation with other elements, such as other provinces, Regency/City Government, Foundation, College or University or College, Research Institute, government agencies in the regions, Cooperatives and Business Entities in legal for, Institutions established by the Government or Provincial and Regency/City Government, 
Community organizations in charge of family resilience or observers of women and child issues; and/or Student organizations.

\subsection{Depok City, West Java}

The Family Resilience Regional Regulation in Depok is the first Regional Regulation in Indonesia that regulates family resilience. The regulation is Depok Government Regulation Number 9 Year. Member of Depok City Parliament, Farida Rachmayanti, said that this Regional Regulation is a follow-up to the 2016 - 2021 regional flagship program, namely Depok Kota Ramah Keluarga (Family Friendly City). The purpose of the establishment of this Regional Regulation to realize the quality of the family in meeting the physical needs of spiritual materials and mental in a balanced manner to carry out the function of the family optimally towards the prosperous family born and inner, as well as harmonization and synchronization of family resilience development efforts organized by the City Government, the community, and the business world [8]. In other words, this regulation is intended to form a prosperous family, quality family, harmonious family because Depok family resilience is a reference for Family Resilience Development and Development in Depok City.

Based on the theory from Lawrence M. Friedman, the legal structure of this regulation is the institutional implementation of family resilience, consisting of Tim Pembina Ketahanan Keluarga, Tenaga lapangan Ketahanan Keluarga, Motivator Ketahanan Keluarga (Montekar), Pendamping Kader Posyandu (PKP), Tenaga Penggerak Kelurahan (TPKel), RW Ramah Anak (is part of the Kota Layak Anak Depok program technically implemented by the Gugus Tugas Kota Layak Anak Depok working closely with Forum Kota Layak Anak coordinated village level).

Legal substance or the output of this regulation is the absence of policies that support Depok facing demographic bonuses such as pre-wedding mentoring, family harmony development, education and childcare, women's empowerment for the improvement of the family economy, institutional family resilience, special family protection, coaching, supervision and control, and strategic partnerships of family resilience, Tribina keluarga, Usaha Peningkatan Pendapatan Keluarga Sejahtera (UPPKS), Pusat Informasi Konseling Remaja (PIK-R) dan RW Ramah Anak. According to the Religious Court (PA) Depok city, from the beginning of January to June 2020, there were 568 married couples (pasutri) divorced, while in the period 2019, there were 3,664 cases of divorce.

Based on this regulation's legal culture adheres to the religious values and sublime culture of the nation. Regarding the cultural value in Depok city society, especially after implementing this Regulation, the community becomes aware of the importance of harmonious families through programs implemented in Depok. But law enforcement agencies are not regulated by these regulations. There are only administrative sanctions.

\section{Conclusion}

Based on the research results, the regional regulations (Perda) about Family Resilience is an outstanding breakthrough for overcoming family problems and strengthening family resilience. However, it is necessary to compromise with the legal culture and legal structure that surrounds it. Also, the substance of local regulations needs to be more comprehensive and cover local communities' needs and wants. In other words, the existence of regional regulations 
(Perda) regarding family resilience in Banjarmasin, Depok, and Banten is a sign that family resilience is an urgent matter to be regulated because it relates to the human resources of this nation, especially this regional regulation to discuss early marriage rates. So, to enforce this regulation, synergy and collaboration from various kinds of stakeholders are needed, starting from local governments, non-governmental organizations that are concerned about the resilience of families and also communities.

\section{Acknowledgment}

The research and writing of this article are financed by Universitas Indonesia 2020 PUTI Research grant based on a contract number NKB-3846/UN2.RST/HKP.05.00/2020. The authors would also like to thank related resource persons namely: 1) Rimalia Salimah, S.K.M, M.M., as Head of The Section of Women Protection Office of Women Empowerment and Children Protection of Banjarmasin City, and 2) Farida Rachmayanti, S.E., M.Si. as Chairwoman of Special Committee of Local Ordinance Bill on Family Resilience and Member of Depok City Parliament.

\section{References}

[1] Kementerian Pemberdayaan Perempuan dan Perlindungan Anak, 2016.

[2] Indonesia, Undang-undang tentang Perkembangan Kependudukan dan Pembangunan Keluarga, 2009.

[3] Kementrian Pemberdayaan Perempuan dan Perlindungan Anak, 2013.

[4] E. Yuandari, F. Razy, and R. T. Rahman, "Problematika Pernikahan Dini Di Kota Banjarmasin," Dinamika Kesehatan Jurnal Kebidanan Dan Keperawatan, vol. 10, no. 2, pp. 622-633, 2019.

[5] Banjarmasin: Pengadilan Agama Banjarmasin kelas 1A, 2018.

[6] Banjarmasin: Pengadilan Agama Banjarmasin kelas 1A, 2018.

[7] Banten: Pemerintah Daerah Banten, 2018.

[8] Depok: Pemerintah Daerah Kota Depok, 2017. 